J. Product. \& Dev., 26(4): 939- 953 (2021)

\title{
EFFECT OF DIFFERENT STIRRING SPEEDS AND DIGESTION MIXTURES ON BIOGAS PRODUCTION
}

Esraa G. Sharaby ${ }^{1}$; Y.M. El-Hadidi ${ }^{2}$ and E. H. El-Hanafy ${ }^{1}$

${ }^{1}$ Soil and Water Science Department, Faculty of Technology and Development, Zagazig University, Egypt

${ }^{2}$ Engineering Agricultural Department, Faculty of Agric., Mansoura University, Egypt

e.mail:.esraagamal5991@gmail.com,ymelhadidi56@yahoo.com

\section{ABSTRACT}

A stainless steel horizontal digester for biogas production was designed, constructed and installed in the biogas laboratory of the Agricultural Engineering Department, Faculty of Agriculture, Mansoura University to investigate the effect of different digestion mixtures (mixture $1(100 \%$ cow manure), mixture 2 (75\% cow manure $+25 \%$ poultry droppings), mixture $3(50 \%$ cow manure $+50 \%$ poultry droppings $)$, and mixture 4 (25\% cow manure $+75 \%$ poultry droppings)) under different stirring speeds (40, 60, and $80 \mathrm{rpm}$ ) on biogas production as a source of renewable energy. Digestion temperature, stirring time and influent total solids were adjusted at $40{ }^{\circ} \mathrm{C}$ and 15 minutes / 4 hours, $10 \%$ respectively. The hydraulic retention time (HRT) was 45 days. During batch process anaerobic digestion of all digestion mixtures, daily biogas production and methane content were measured. The biogas calorific value were determined. Biochemical oxygen demand (BOD) of influent and effluent slurries was determined to calculate the digestion process efficiency. Chemical analysis for different influents and effluents was also carried out.

Conclusively, the obtained results indicated that, biogas production of mixture 3 is more than other mixtures. It is advised to use stirring speed of $80 \mathrm{rpm}$ with stirring time 15 minutes every 4 hours at total solid of 10\%, digestion temperature $40^{\circ} \mathrm{C}$ and $45 \mathrm{HRT}$. According to chemical analysis, the effluent slurry could be used as a good organic fertilizer.

Key words: Biogas, anaerobic digestion, stirring speed, stirring time, temperature, cow manure, poultry droppings.

\section{INTRODUCTION}

Animal production has recently attracted public interest, according to ElHadidi and Al-Turki (2007), animal and poultry wastes have been produced in 
significant volumes on tiny spaces due to the expansion of livestock and poultry housings in recent years.

Kerssen (2015) and Gyuseong et al., (2018) added that, it is essential to find a technologically and economically workable way to treat large amounts of manure and wastewater. Anaerobic digestion (AD) is considered one of the most appropriate technologies in manure and wastewater treatment due to the amounts of biogas produced and its economic relevance in addition to the possibility to solve the problems of manure waste environmental pollution and utilization at the same time. In the same trend, Blumenstein et al., (2016), Cowley and Brorsen (2018) and Scarlat et al., (2018) reported that anaerobic digestion (AD) is a cost effective and environmentally-friendly method that can treat and recover bioenergy from different types of organic wastes. AD of livestock wastes such as chicken and cow manures could bring significant environmental and economic benefits, including water and air pollution control, and renewable energy production. Gebrezgabher et al., (2010) and Yong et al., (2015) mentioned that, $\mathrm{AD}$ is a biological process for the conversion of waste materials to energy sources through the treatment of several organic residuals.

The production of biogas from manures is a cost effective option, because not only does it resolve an environmental problem of raise raw manure but it also lets the livestock farms to become self-sustaining in electrical and/or heat energy supply. Renewable technologies can provide electricity, cooking gas, and heating in locations where domestic energy infrastructures do not reach, according to De Oliveira et al., (2011) and Insam et al., (2014).

Shirzad et al., (2019) reported that, biogas is a promising renewable energy source that can be utilized for a variety of purposes, including transportation, heating, and electricity generation. Petersson, (2013) told that biogas refers to the mixture of gases created during the anaerobic digestion process. Biogas is mostly made up of methane and carbon dioxide, with minor amounts of other chemicals such as water, hydrogen sulfide, and ammonia.

If the fermentation components are excessively diluted or too concentrated, biogas production will be insufficient (Abbasi et al., 2012). Solid matter and water make up all waste products fed into a plant. Volatile and non-volatile substances make up solid matter (Xu et al., 2014). Volatile solids are digested during the anaerobic fermentation process, but non-volatiles are unaffected. It has been determined that the optimum solids content in the digestion of sewage sludge is between $8 \%$ and $10 \%$ (Khoiyangbam et al., 2011).

The temperature of anaerobic digestion is a critical operational parameter that influences the metabolic activity of microorganisms and the efficiency of anaerobic digestion (Liu et al., 2018; Zhao et al., 2018; Feng et al., 2019 and 
Wang et al., 2019). In modest biogas plants, the most successful working temperature of the slurry was stated to be $20-45^{\circ} \mathrm{C}$ (Ortega et al., 2008). Anaerobic fermentation has a $\mathrm{pH}$ range of 6.8 to 8.0, and efficient digestion occurs at a pH similar to neutral (Zhai et al., 2015). For optimum degradation a $(\mathrm{C} / \mathrm{N})$ ratio of 20 - 30 is often recommended Nitrogen present in the feedstock has two benefits; the first one is providing an essential element for synthesis of amino acids, proteins and nucleic acids, while the second one is converted it to ammonia which, as a strong base, neutralizes the volatile acids produced by fermentative bacteria, and thus helps maintain neutral $\mathrm{pH}$ conditions essential for cell growth Steffen et al., (2000).

Digestion material must be stirred to distribute the substrates and maintain a consistent level of microorganisms and heat, it helps to drive out gas bubbles and avoid the formation of floating or settling layers by enhancing the contact between bacteria and their food. Agitation in the digester can be done mechanically or manually, and it can be situated vertically or horizontally. Agitation is also used to break up the floating scum layer that can form in feedstock containing high amounts of other elements, such as wood chips, which can be present in some types of manure, such as chicken manure, Bensmann et al., (2013); Tian et al., (2015) and Mao et al., (2015).

Therefore, this research work was aimed to investigate the effect of various digestion mixtures under different stirring speeds on biogas production.

\section{MATERIALS AND METHODS}

A stainless steel horizontal digesters for biogas production (Figures 1 and 2) were designed, constructed and installed in the biogas laboratory of the Agricultural Engineering Department, Faculty of Agriculture, Mansoura University. Each digester having a gross dimensions of $800 \mathrm{~mm}$ length $250 \mathrm{~mm}$ diameter and $1 \mathrm{~mm}$ thickness with a total volume of $0.039 \mathrm{~m}^{3}$. To reduce heat losses from the digesters, glass wool is utilized to insulate the curved surface area of the digesters with a thickness of $10 \mathrm{~mm}$.

A mechanical stirrer, consisting of a steel shaft with a length of $1000 \mathrm{~mm}$ and $12 \mathrm{~mm}$ diameter, was installed in the digester. The shaft has four blades, each with $150 \mathrm{~mm}$ length, $40 \mathrm{~mm}$ width and $20 \mathrm{~mm}$ thickness. The stirrers are operated via electric motor $(550 \mathrm{~W})$. The mixing speed was adjusted using an electric inverter to give different rotational speed for stirring shaft. Stirring is essential for keeping the contents of the digester homogeneous and for maintaining as uniform a temperature distribution inside the digester. 


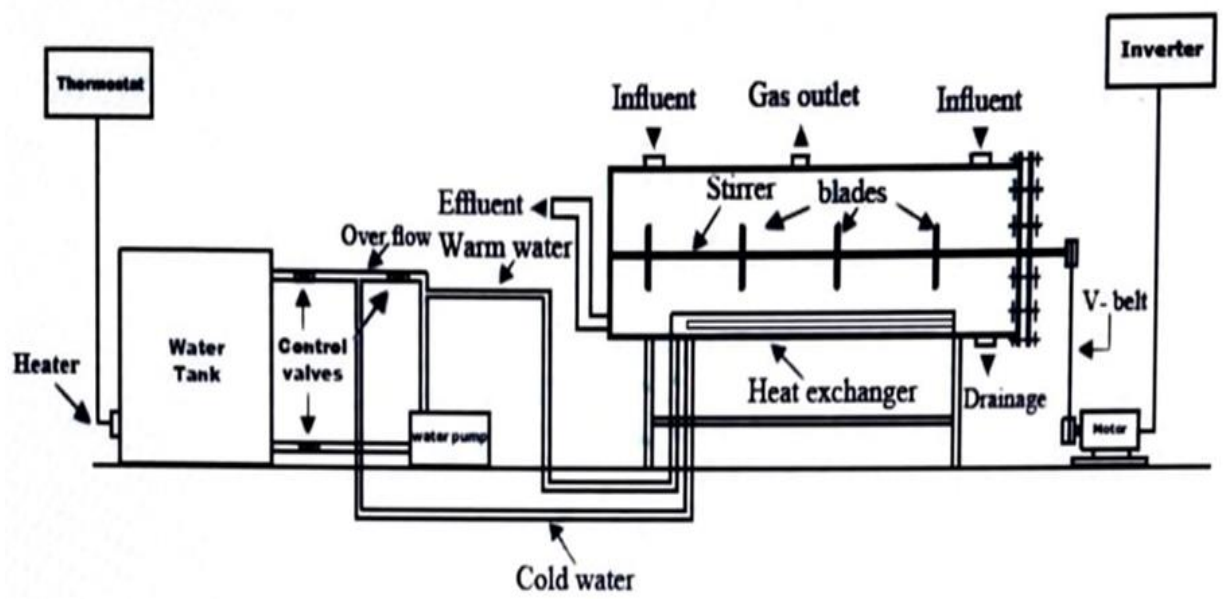

Figure (1): Schematic diagram for the biogas experimental unit.
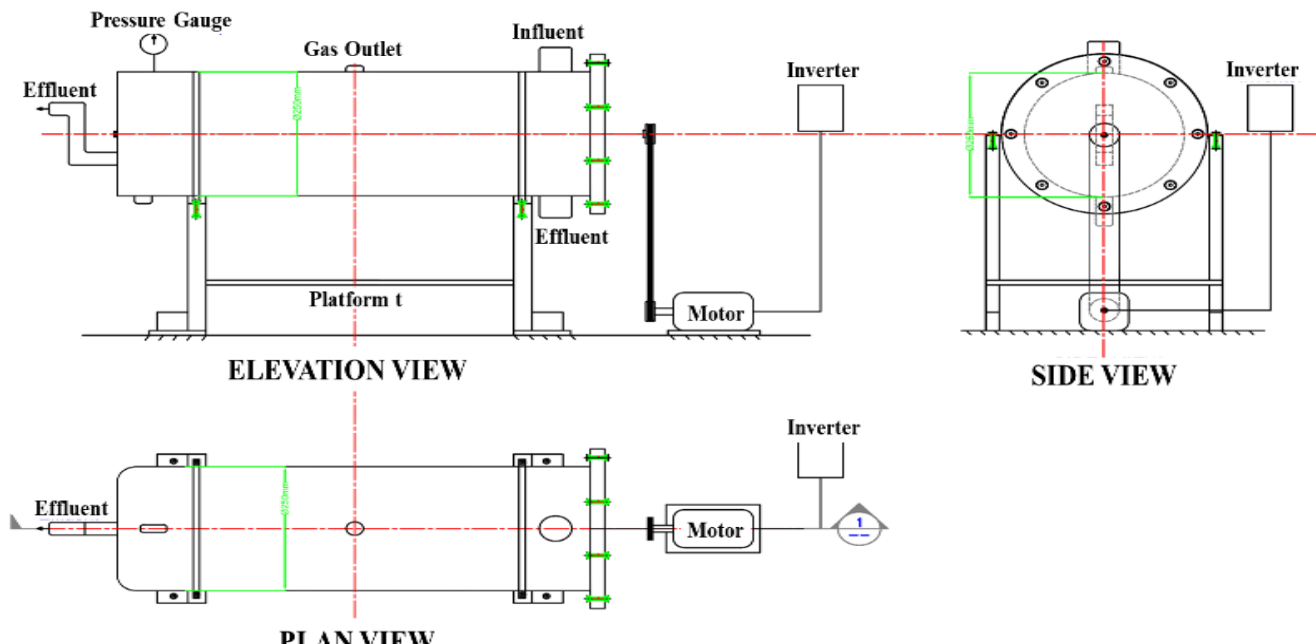

Figure (2): Elevation, plan and side view of the biogas experimental unit.

A heating water tank with dimensions of $380 \mathrm{~mm}$ width, $400 \mathrm{~mm}$ length, and $300 \mathrm{~mm}$ height makes up the heating system. To reduce heat losses, the water tank was insulated with $10 \mathrm{~mm}$ thick glass wool insulation. To reduce water evaporation, bio-balls were placed on the water's surface. To keep the temperature at a specified level, an electrical heater $(1 \mathrm{~kW})$ was used, which was regulated by an electrical digital thermostat (model EWPC 902/T/R/P and 220V / 100A). The heating system was employed to keep the digested slurry at the proper temperature. Using an immersed heat exchanger, the fermented slurry was heated 
with hot water to maintain the appropriate temperature level. The heat exchanger, which was composed of stainless steel tubing with $12.5 \mathrm{~mm}$ diameter and 2000 mm length, was installed at the bottom of the digester.

Fresh cow manure was collected from animal farm in Kafr El Zayat, Gharbiya Governorate, while fresh poultry droppings was obtained from Layers chicken farm in Diarb Negm, El Sharqyia Governorate, Egypt.

The biogas units were fed with liquid slurry having a total volume $0.030 \mathrm{~m}^{3}$ and a total solids was $10 \%$. The following equation was assigned for appreciation amount of water according to (LO et al., 1981):

$$
\boldsymbol{Y}=\frac{X\left(T s_{\operatorname{man}}-T s_{\text {dig }}\right)}{T s_{\text {dig }}} \ldots \ldots \ldots
$$

Where:

$\mathrm{Y}=$ The amount of water required for dilution, $(\mathrm{kg})$.

$\mathrm{X}=$ The amount of manure added (raw material), $(\mathrm{kg})$.

$\mathrm{TS}_{\mathrm{man}}=$ The total solids of manure (raw material), $\%$.

$\mathrm{TS}_{\text {dig }}=$ The total solids of influent (digestion material), (10\%).

The following indicators were taken into consideration in order to evaluate the effect of study factors on biogas production.

Studying factors: different digestion mixtures (mixture $1(100 \%$ cow manure), mixture 2 (75\% cow manure $+25 \%$ poultry droppings), mixture $3(50 \%$ cow manure $+50 \%$ poultry droppings), and mixture 4 (25\% cow manure $+75 \%$ poultry droppings) under different stirring speeds (40, 60, and $80 \mathrm{rpm})$. Digestion temperature, stirring time and influent total solids were adjusted at $40{ }^{\circ} \mathrm{C}$ and 15 minutes / 4 hours, $10 \%$ respectively. The hydraulic retention time was 45 days.

\section{Biogas yield and calorific value:}

At room temperature and atmospheric pressure, the daily biogas production was volumetrically quantified using a Ritter gas meter., room temperature and ambient room pressure were measured daily to recalculate the volume of daily biogas production under standard conditions (STP) as mentioned by (Gosch $\boldsymbol{e t}$ $a l .$, 1983) using the following equation:

$$
V_{t r}=\frac{V_{f}\left[273.15\left(P_{1}-P_{2}-P_{3}\right)\right]}{[273.15+T] 1013}, \mathbf{m}^{3} \text {. }
$$

Where:

$\mathrm{V}_{\mathrm{tr}}=$ Volume of dry gas under standard conditions,

$V_{\mathrm{f}}=$ Volume of wet gas at pressure $\mathrm{P}_{2}$ and ambient temperature $\mathrm{T}, \mathrm{m}^{3}$.

$\mathrm{P}_{1}=$ Air pressure at temperature $\mathrm{T}$,

millibar.

$\mathrm{P}_{2}=$ Pressure of wet gas at gas temperature $\mathrm{T}$,

millibar.

$\mathrm{P}_{3}=$ Saturation steam pressure of water at temperature $\mathrm{T}, \quad$ millibar.

$\mathrm{T}=$ Temperature of wet gas in, ${ }^{\mathrm{O}} \mathrm{C}$. 
The calorific value and density of biogas under standard conditions were considered to be $50 \mathrm{MJ} / \mathrm{kg}\left(36 \mathrm{MJ} / \mathrm{m}^{3}\right)$ and $0.72 \mathrm{~kg} / \mathrm{m}^{3}$, respectively according to Mitzlaff, (1988). The calorific value of the produced biogas at standard condition (STP) was calculated according equation (3):

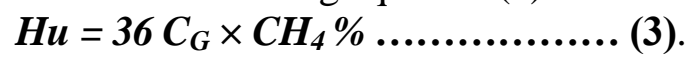

Where:

$\mathrm{Hu}=$ Calorific value of biogas at standard conditions,

$\mathrm{C}_{\mathrm{G}}=$ Cumulative biogas production under standard conditions,

$\mathrm{CH}_{4} \%=$ Methane proportion in biogas,

$36=$ The calorific value of methane at standard conditions,

MJ.

$\mathrm{m}^{3}$.

Percent.

Methane content (\%) of the produced biogas was measured by biogas

Analyzer Model (GAS 5000).

To obtained the Total solids $\left(\mathrm{T}_{\mathrm{S}}\right)$ of samples of raw material (cow manure and poultry droppings), influent and effluent were oven-dried at $105{ }^{\circ} \mathrm{C}$ for about $24 \mathrm{hr}$ to constant weigh according to (APHA, 1989). Percentage of total solids was calculated as follows:

$$
T_{s}=\frac{W_{D}}{W_{W}} \times 100
$$

Where:

$\mathrm{W}_{\mathrm{D}}=$ The weight of sample after drying,

g.

$\mathrm{W}_{\mathrm{W}}=$ The weight of sample before drying,

g.

Volatile solids $\left(\mathrm{V}_{\mathrm{S}}\right)$ was calculated by using the following equation as mentioned by APHA (1989). Digital Muffle Furnace was used to ignite raw material (the dried samples) at $600{ }^{\circ} \mathrm{C}$ for two hours.

$$
V_{S}=100-\operatorname{ash}(\%)
$$

Ash percentage can be defined as the residual solid produced from burning raw material (cow manure or poultry dropping) influent and effluent inside the Muffle Furnace.

Total nitrogen and organic carbon in the organic wastes (influent) and the anaerobically digested (effluent) were measured in the laboratory of Soil and Water Science department, Faculty of Technology and Development, Zagazig University.

Biochemical oxygen demand (BOD) of the influent and effluent was measured in the laboratory of Dakahlia Drinking Water and Sanitation Company. The following equation was used to determine the efficiency of digestion process according to Abd El-Magid (2003):

Where:

$$
\operatorname{DPE}(\%)=\frac{B O D_{I n}-B O D_{E f}}{B O D_{I n}} \times 100
$$

$\mathrm{DPE}=$ Digestion Process Efficiency,

$\%$ 
$\mathrm{BOD}_{\text {In }}=\mathrm{BOD}$ influent

$\mathrm{mg} / \mathrm{l}$.

$\mathrm{BOD}_{\mathrm{Ef}}=\mathrm{BOD}$ effluent, $\mathrm{mg} / \mathrm{l}$.

Excel spreadsheet was used to calculate the total solids contents, ash contents, the volatile solids and organic carbon. It was used also throughout the experimental work to calculate some measurements such as biogas production, influent raw material (cow manure and poultry droppings), digested slurry (effluent) characteristics and biogas compositions at different treatments.

A SPSS statistical analysis program was used to test the significant differences between the treatments.

\section{RESULTS AND DISCUSSIONS}

Under the experimental conditions ( 15 minutes every $4 \mathrm{hr}$ stirring time, 40 ${ }^{\circ} \mathrm{C}$ digestion temperature, $10 \%$ total solids of influent slurry and 45 day HRT), the results illustrated in Fig. (3) showed that at 40 rpm stirring speed, the cumulative biogas production was $148.1,318.38,565.19$ and 285.95 liters for mixtures $1,2,3$ and 4 , respectively. This means that the produced biogas from mixture 3 was 281.6, 77.5 and $97.65 \%$ higher than that produced from mixtures 1,2 and 4 respectively. Also, it is noticed that, the greatest daily biogas production of different mixtures was 17.88, 30.71, 41.79 and 33.29 liters for mixtures 1, 2, 3 and 4 respectively. These values were reached on fifteenth day.

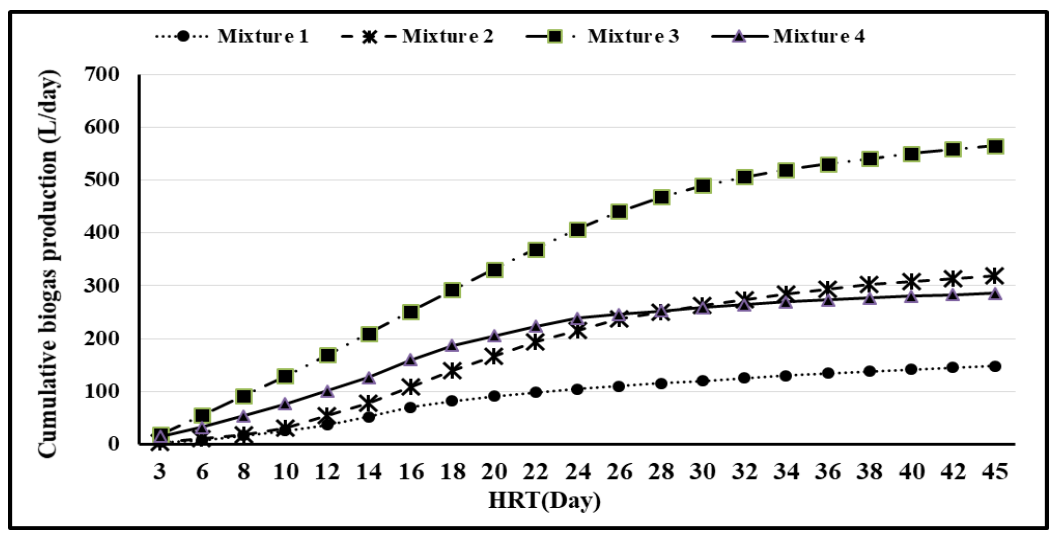

Figure (3): Cumulative biogas production of different mixtures at stirring speed (40 rpm).

Figure (4) showed that at $60 \mathrm{rpm}$ stirring speed, the cumulative biogas production was 186.6, 407.18, 596.92 and 348.57 liters for mixtures 1, 2, 3 and 4, respectively. This means that the produced biogas from mixture 3 was 219.89 , 46.59 and $71.24 \%$ higher than that produced from mixtures 1,2 and 4 respectively. The results indicated also that, the highest daily produced biogas was 
25.22, 43.35, 44.3 and 31.27 liters for mixtures 1, 2, 3 and 4 respectively. These value was reached on fifteenth day.

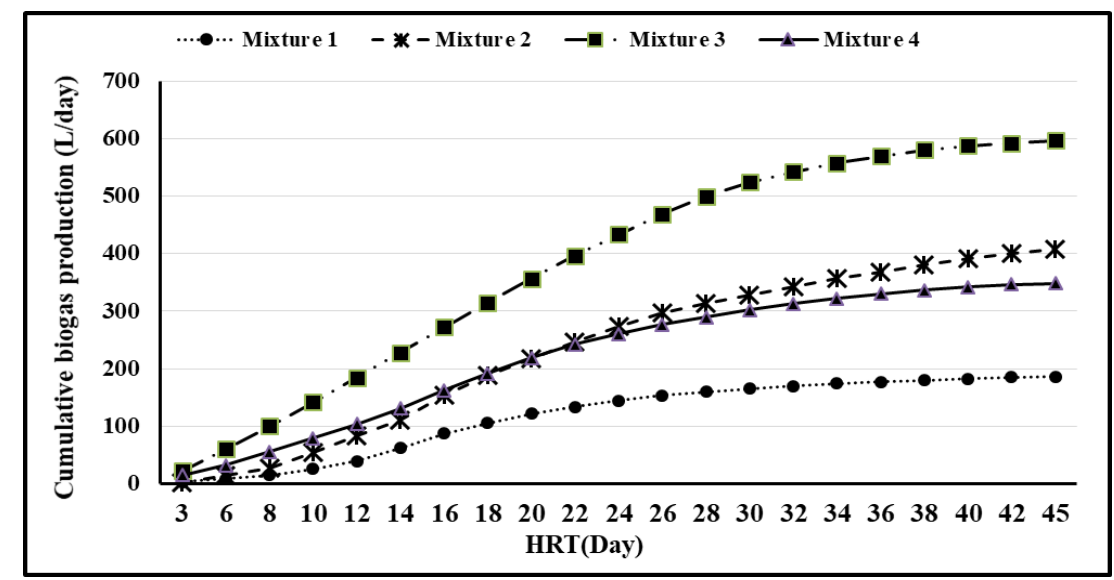

Fig. (4): Cumulative biogas production of different mixtures at stirring speed (60 rpm).

At $80 \mathrm{rpm}$ stirring speed, the results in Fig. (5) Showed that the cumulative biogas production obtained was 227.83, 512.5, 623.63 and 401.96 liters for mixtures (1), (2), (3) and (4), respectively. This means that biogas produced from mixture (3) was 173.7, 21.68 and $55.14 \%$ higher than that produced from mixtures (1), (2) and (4) respectively. The highest daily biogas produced was 26.29, 46.52, 45.3 and 34.82 liters for mixtures 1, 2, 3 and 4 respectively. These value was reached on fourteenth and fifteenth days. The statistical analysis showed high significant differences at $1 \%$ level among different mixtures and stirring speeds in biogas production. 


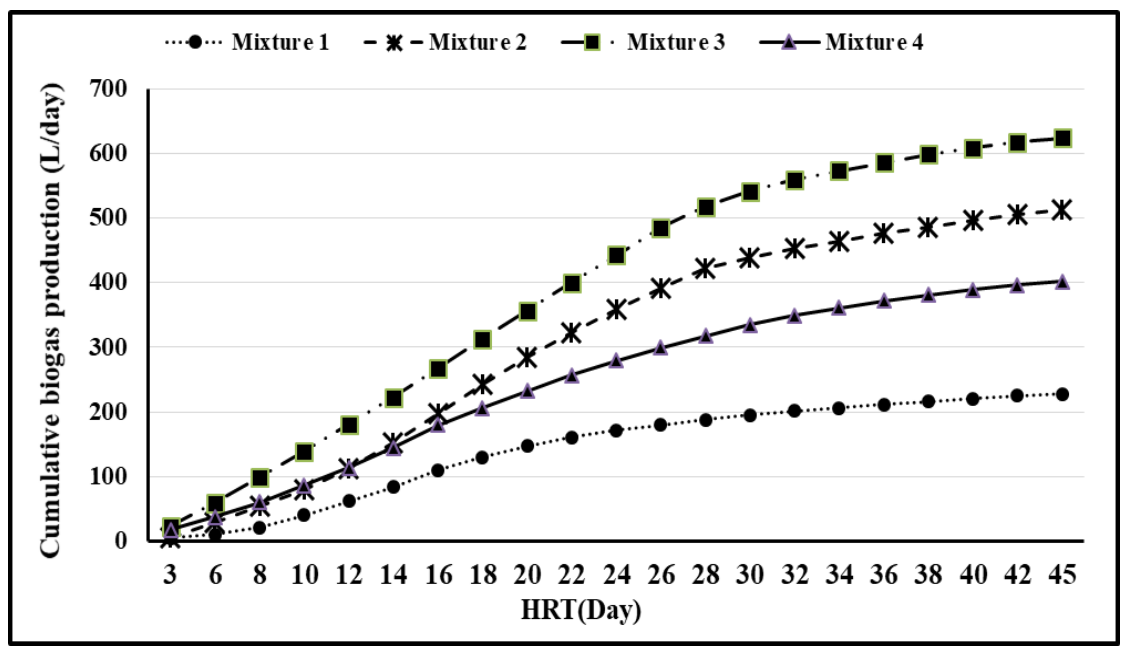

Fig. (5): Cumulative biogas production of different mixtures at stirring speed $(80 \mathrm{rpm})$. Methane content of the produced biogas:

The results tabulated in Table (1) show the average methane content of the produced biogas from different mixtures under the three studied stirring speeds. It can be seen that the concentration of methane in the biogas was 74.18, 75.15 and 74.28 percent for mixture (1), 72.4, 71.85 and 73.61 percent for mixture (2), $76.54,75.49$ and 78.25 percent for mixture (3) and 73.18, 74.32 and 76.48 percent for mixture (4) at 40, 60 and $80 \mathrm{rpm}$ stirring speed respectively. It can be seen that methane concentration of each studied mixture increased by increasing the stirring speed while the variation of accumulative biogas production and also the methane concentration in the biogas of different mixtures may be due to the differences in the composition of the mixtures.

Table (1): Methane content of the produced biogas

\begin{tabular}{|c|c|c|c|c|}
\hline \multirow[t]{2}{*}{ Mixture } & \multicolumn{3}{|c|}{ Stirring speeds, rpm } & \multirow{2}{*}{$\begin{array}{c}\text { Mean, } \\
\%\end{array}$} \\
\hline & 40 & 60 & 80 & \\
\hline 1 & 74.18 & 75.15 & 74.28 & 74.53 \\
\hline 2 & 72.4 & 71.85 & 73.61 & 72.62 \\
\hline 3 & 76.54 & 75.49 & 78.25 & 76.76 \\
\hline 4 & 73.18 & 74.32 & 76.48 & 74.66 \\
\hline
\end{tabular}

\section{Calorific value of biogas production (MJ):}

Under the studied experimental conditions, Fig. (6) Presents the calorific value of biogas production in all experiments. The calorific value in the generated biogas was calculated using equation (3) as recommended by Mizlaff (1988). The results indicated that, at $40 \mathrm{rpm}$ stirring speed, the calorific value of the produced 
biogas was 3.96, 8.30, 15.57 and 7.53 MJ for mixture (1), mixture (2), mixture (3) and mixture (4), respectively, while it was 5.05, 10.53, 16.03 and 9.33 MJ at 60 rpm for mixture (1), mixture (2), mixture (3) and mixture (4), respectively. The results also showed that, at $80 \mathrm{rpm}$ stirring speed, the calorific value of biogas generation was 6.09, 13.58, 17.57 and 11.07 MJ for mixture (1), mixture (2), mixture (3) and mixture (4), respectively. The results revealed that, the calorific value of biogas production of mixture (3) are always higher than calorific value of biogas production for other digestion mixtures at all treatments. The above mentioned results may be due to the differences in the composition of the studied mixtures.

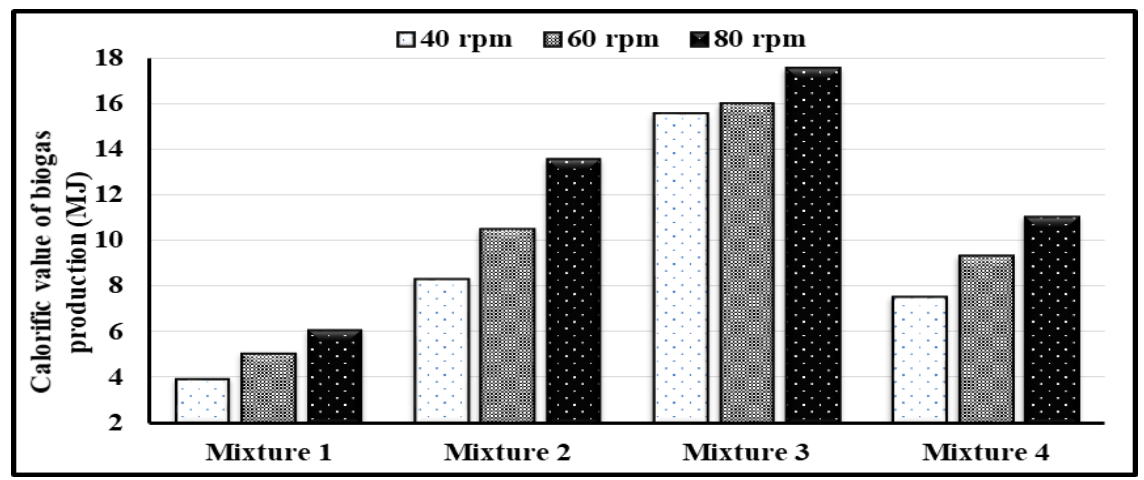

Fig. (6): Calorific value of different mixtures under different stirring speeds.

\section{Digestion process efficiency:}

The digestion process efficiency of different digested mixtures was calculated using equation (6) as mentioned by Abd El-Magid (2003) and the obtained data illustrated in Fig. (7). The results showed that, the digestion process efficiency was $71.7,66.5,71.9$ and $68.2 \%$ at $40 \mathrm{rpm}$ stirring speed for mixture (1), mixture (2), mixture (3) and mixture (4), respectively, while it was 72.6, 69.6, 72.9 and $70.8 \%$ at $60 \mathrm{rpm}$ stirring speed for mixture (1), mixture (2), mixture (3) and mixture (4), respectively. The results showed also that at $80 \mathrm{rpm}$ stirring speed, the digestion process efficiency was 74.2, 70.0, 74.3 and $71.1 \%$ for mixture (1), mixture (2), mixture (3) and mixture (4), respectively. The results revealed that, the digestion process efficiency of mixture 3 are always higher than calorific value of biogas production for other digestion mixtures at all treatments. These results are in line with that obtained by El-Hadidi and Al-Turki (2007). 


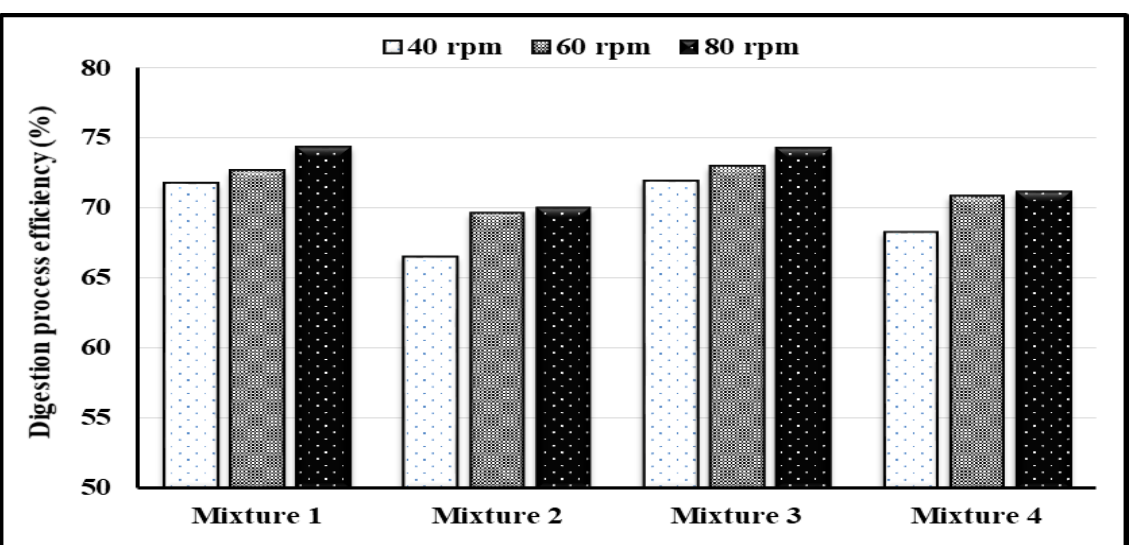

Fig. (7): Digestion process efficiency of different mixtures under different stirring speeds.

\section{Effluent slurry characteristics:}

Chemical analysis of influent and effluent slurries of different mixtures were tabulated in Tables 2 and 3 respectively. It can be said that, the effluent slurry of different digested mixtures considered as a good fertilizer and soil conditioner. These results are in line with that obtained by EL-Hadidi and Seufert (1997); Odlare et al., (2008) and Albuquerque et al., (2012a, b). It is evident from Tables $(2,3)$ that the percentage of nitrogen, phosphorus, and potassium for the effluent slurry of mixture (3) were 19.4, 57.5, and $21.7 \%$ higher than the influent slurry for the same mixture.

Table (2): Chemical analysis of influent slurry of different mixtures.

\begin{tabular}{|c|c|c|c|c|c|}
\hline \multirow[t]{2}{*}{ Mixture } & \multicolumn{5}{|c|}{ Constituent } \\
\hline & $\mathrm{N}, \%$ & $\mathbf{P}, \%$ & $\mathrm{~K}, \%$ & $\mathrm{C} / \mathrm{N}$ & $\mathrm{pH}$ \\
\hline$\overline{1}$ & 2.43 & 1.89 & 3.48 & 20.04 & 6.40 \\
\hline 2 & 2.26 & 0.88 & 3.30 & 17.48 & 6.46 \\
\hline 3 & 2.79 & 0.40 & 3.45 & 17.01 & 6.65 \\
\hline 4 & 2.15 & 0.70 & 3.37 & 24.13 & 6.60 \\
\hline
\end{tabular}

Table (3): Chemical analysis of different digested mixtures (effluent slurry).

\begin{tabular}{|c|c|c|c|c|c|c|}
\hline \multirow[b]{2}{*}{ Mixture } & \multirow{2}{*}{$\begin{array}{c}\text { Stirring speed, } \\
\text { rpm }\end{array}$} & \multicolumn{5}{|c|}{ Constituent } \\
\hline & & $\mathrm{N}, \%$ & P, \% & $\mathrm{K}, \%$ & $\mathbf{C} / \mathbf{N}$ & pH \\
\hline \multirow{3}{*}{1} & 40 & 2.49 & 2.06 & 3.58 & 18.91 & 7.15 \\
\hline & 60 & 2.52 & 2.12 & 3.85 & 18.21 & 7.20 \\
\hline & 80 & 2.61 & 2.25 & 3.90 & 16.81 & 7.25 \\
\hline
\end{tabular}




\begin{tabular}{|c|c|c|c|c|c|c|}
\hline \multirow{2}{*}{2} & 40 & 2.42 & 0.91 & 3.40 & 15.99 & 7.20 \\
\hline & 60 & 2.50 & 0.95 & 3.59 & 14.81 & 7.25 \\
\hline \multirow{3}{*}{$\mathbf{3}$} & 80 & 2.61 & 1.27 & 3.72 & 13.76 & 7.45 \\
\hline & 40 & 2.88 & 0.45 & 3.66 & 16.20 & 7.72 \\
\hline & 60 & 3.01 & 0.51 & 3.91 & 14.85 & 7.75 \\
\hline & 80 & 3.33 & 0.63 & 4.20 & 12.69 & 7.80 \\
\hline & 40 & 2.24 & 0.90 & 3.65 & 22.09 & 7.70 \\
\hline & 60 & 2.35 & 0.96 & 3.74 & 20.20 & 7.90 \\
\hline & 80 & 2.41 & 1.21 & 4.01 & 18.88 & 8.00 \\
\hline
\end{tabular}

\section{CONCLUSION}

1- Biogas production was higher in the digestion mixture 3 (50\% cow manure + $50 \%$ poultry droppings) than in the other digestion mixtures.

2- According to chemical analysis, the produced effluent slurry might be used as a good organic fertilizer with good concentration of plant nutrients (N, P and K).

3 - It is recommended to use stirring speed of $80 \mathrm{rpm}$ with digestion mixture $(50 \%$ cow manure $+50 \%$ poultry droppings) at digestion temperature $40 \mathrm{oC}$, stirring time 15 minute / 4 hours and total solids $10 \%$ in order to get the greatest biogas production with high methane content and calorific value.

\section{REFERENCES}

Abbasi, T., Tauseef, S. M., and Abbasi, S. A. (2012). Biogas and Biogas Energy: an introduction. In Biogas Energy (pp. 1-10). Springer, New York, NY.

Abdel- Magid, H. M. (2003). Wastewater: Characteristics, treatment and utilization. 1st ed., King Saud Univ. Kingdom of Saudi Arabia.

Alburquerque, J. A., de la Fuente, C., and Bernal, M. P. (2012a). Chemical properties of anaerobic digestates affecting $\mathrm{C}$ and $\mathrm{N}$ dynamics in amended soils. Agriculture, Ecosystems \& Environment, 160, 15-22.

Alburquerque, J. A., de la Fuente, C., Ferrer-Costa, A., Carrasco, L., Cegarra, J., Abad, M., and Bernal, M. P. (2012b). Assessment of the fertiliser potential of digestives from farm and agroindustrial residues. Biomass and bioenergy, 40, 181-189. 
APHA (American Puplic Health Assocition). (1989). "Standard Methods For The Examination Of Water And Waste Water" 17th. ed. Washington, D.C. USA

Bensmann, A., Hanke-Rauschenbach, R., and Sundmacher, K. (2013). Reactor configurations for biogas plants-a model based analysis. Chemical Engineering Science, 104, 413-426.

Blumenstein, B., Siegmeier, T., and Möller, D. (2016). Economics of anaerobic digestion in organic agriculture: Between system constraints and policy regulations. Biomass and Bioenergy, 86, 105-119.

Cowley, C., and Brorsen, B. W. (2018). Anaerobic digester production and cost functions. Ecological Economics, 152, 347-357.

De Oliveira, S. V. W. B., Leoneti, A. B., Caldo, G. M. M., and De Oliveira, M. M. B. (2011). Generation of bioenergy and biofertilizer on a sustainable rural property. Biomass and bioenergy, 35(7), 2608-2618.

EL-Hadidi, Y. M. and Seufert, H. (1997). Possibilities of increasing biogas production by using different mixtures of animal wastes. Misr J. Ag. Eng., 14(1), 17-26.

El-Hadidi, Y. M., and Al-Turki, A. I. (2007). Organic fertilizer and biogas production from poultry wastes.Journal of Food Agriculture and Environment, 5(1), 228.

Feng, S., Hou, S., Huang, X., Fang, Z., Tong, Y., and Yang, H. (2019). Insights into the microbial community structure of anaerobic digestion of municipal solid waste landfill leachate for methane production by adaptive thermophilic granular sludge. Electronic Journal of Biotechnology, 39, 98106.

Gebrezgabher, S. A., Meuwissen, M. P., Prins, B. A., and Lansink, A. G. O. (2010). Economic analysis of anaerobic digestion-A case of Green power biogas plant in The Netherlands. NJAS-Wageningen Journal of Life Sciences, 57(2), 109-115.

Gosch, A., Hildegart A., Ursula, W. and Walter, J. (1983). "The anaerobic treatment of poultry manure". Animal Res. and Dev., Vol. 17:62-73.

Gyuseong, H., Seung, G.S., Kyungjin, C., Joonyeob, L., Woong, K., and Seokhwan, H., (2018). Temporal variation in bacterial and methanogenic communities of three full-scale anaerobic digesters treating swine wastewater. Environ. Sci. Pollut. R. 1, 1-10.

Insam, H., Franke-Whittle, I. H., and Podmirseg, S. M. (2014). Agricultural waste management in Europe, with an emphasis on anaerobic digestion. Journal of Integrated Field Science, 11, 13-17. 
Kerssen, T. M. (2015). Food sovereignty and the quinoa boom: challenges to sustainable re-peasantisation in the southern Altiplano of Bolivia. $3^{\text {rd }}$ World Quarterly, 36(3), 489-507.

Khoiyangbam, R. S., Gupta, N., and Kumar, S. (2011). Biogas Technology: towards sustainable development. The Energy and Resources Institute (TERI).

Liu, C., Wachemo, A. C., Tong, H., Shi, S., Zhang, L., Yuan, H., and Li, X. (2018). Biogas production and microbial community properties during anaerobic digestion of corn stover at different temperatures. Bioresource technology, 261, 93-103.

Lo, K. V., W. M. Carson and K. Jeffers (1981). A computer - aided design program for biogas production from animal manure. Livestock Wastes: A Renewable Resources: 133-135, 141

Mao, C., Feng, Y., Wang, X., and Ren, G. (2015). Review on research achievements of biogas from anaerobic digestion. Renewable And Sustainable Energy Reviews, 45, 540-555.

Mitzlaff, K.V. (1988). "Engines For Biogas" GATE Rep., Braunschweig, Germany: 27-33.

Odlare, M., Pell, M., and Svensson, K. (2008). Changes in soil chemical and microbiological properties during 4 years of application of various organic residues. Waste management, 28(7), 1246-1253.

Ortega, L., Barrington, S., and Guiot, S. R. (2008). Thermophilic adaptation of a mesophilic anaerobic sludge for food waste treatment. Journal of Environmental Management, 88(3), 517-525.

Petersson, A. (2013). Biogas cleaning. In The biogas handbook (pp. 329-341). Woodhead Publishing.

Scarlat, N., Fahl, F., Dallemand, J. F., Monforti, F., and Motola, V. (2018). A spatial analysis of biogas potential from manure in Europe. Renewable and Sustainable Energy Reviews, 94, 915-930.

Shirzad, M., Panahi, H. K. S., Dashti, B. B., Rajaeifar, M. A., Aghbashlo, M., and Tabatabaei, M. (2019). A comprehensive review on electricity generation and GHG emission reduction potentials through anaerobic digestion of agricultural and livestock/slaughterhouse wastes in Iran. Renewable and Sustainable Energy Reviews, 111, 571-594. https://doi.org/10.1016/j.rser.2019.05.011.

Steffen, R., Szolar, O., and Braun, R. (2000). Feed stock for anaerobic digestion. Making energy and solving modern waste problem.

Tian, L., Zou, D., Yuan, H., Wang, L., Zhang, X., and Li, X. (2015). Identifying proper agitation interval to prevent floating layers formation of 
corn Stover and improve biogas production in anaerobic digestion. Bioresource technology, 186, 1-7.

Wang, S., Ma, F., Ma, W., Wang, P., Zhao, G., and Lu, X. (2019). Influence of temperature on biogas production efficiency and microbial community in a two-phase anaerobic digestion system. Water, 11(1), 133.

Xu, F., Wang, Z. W., Tang, L., and Li, Y. (2014). A mass diffusion-based interpretation of the effect of total solids content on solid-state anaerobic digestion of cellulosic biomass. Bioresource Technology, 167, 178-185.

Yong, Z., Dong, Y., Zhang, X., and Tan, T. (2015). Anaerobic co-digestion of food waste and straw for biogas production. Renewable Energy, 78, 527-530.

Zhai, N., Zhang, T., Yin, D., Yang, G., Wang, X., Ren, G., and Feng, Y. (2015). Effect of initial $\mathrm{pH}$ on anaerobic co-digestion of kitchen waste and cow manure. Waste management, 38, 126-131.

Zhao, J., Westerholm, M., Qiao, W., Yin, D., Bi, S., Jiang, M., and Dong, R. (2018). Impact of temperature and substrate concentration on degradation rates of acetate, propionate and hydrogen and their links to microbial community structure. Bioresource Technology, 256, 44-52.

\section{تأثير سرعة التقليب ومخاليط الهضم المختلفة على إنتاج الغاز الحيوي \\ إسراء جمال شرابي - ياسر مختار الحديدي - عصام حسني الحنفي

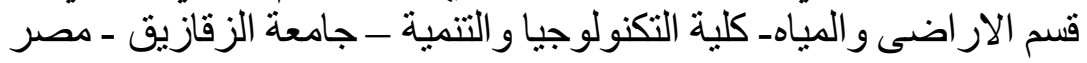

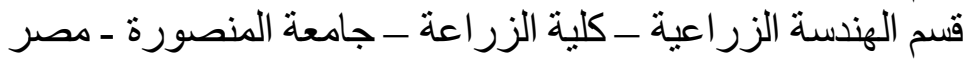

تم إجر اء هذا البحث بمعمل الغاز الحيوى ـ قسم الهندسة الزر اعية ـ كلية الزر اعة ـ جامعة المنصورة بهدف دراسة تأثير سرعة التقليب ومخاليط الهضم المختلفة علي انتاج الغاز الحيوي، وذللك بخلط روث الابقار وزرق الدو اجن بنسب مختلفة شملت

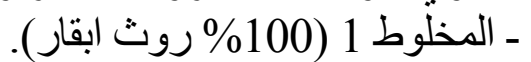

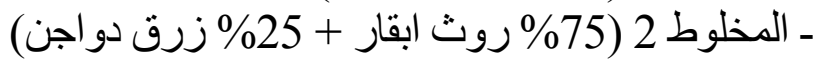

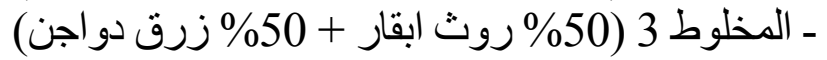

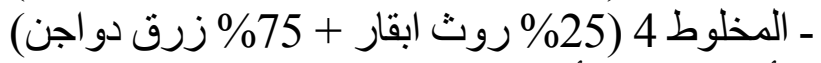

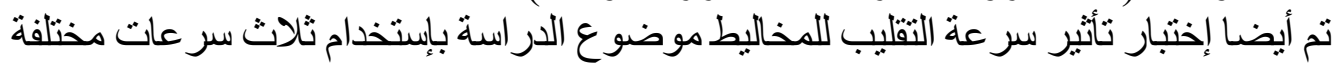

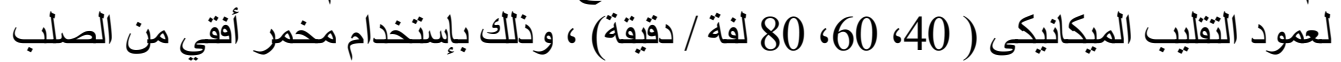

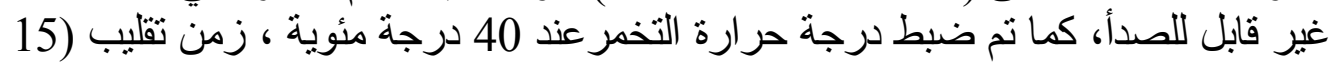
دقيقة / 4 ساعات ) و 10 \% مادة صلبة عند زمن مكوث 45 يوما لجميع التجارب. 
تم قياس وتسجيل الغاز اليومي الناتج ومحتواه من الميثان، كذلك تم حساب القيمة الحرارية للغاز الناتج وحساب كفاءة عملية الهضم، كما تم اجر اء التحان التحليل الكيميائي للمحاليل المتخمرة قبل وبعد عملية الهضم اللاهو ائي.

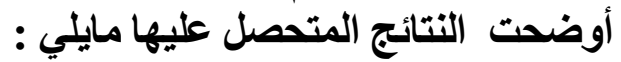

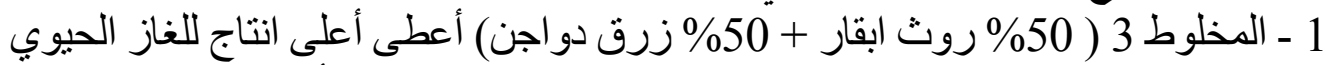

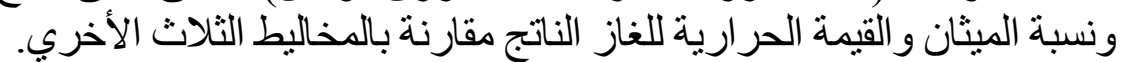

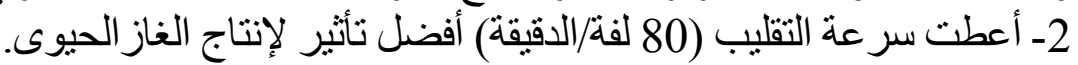

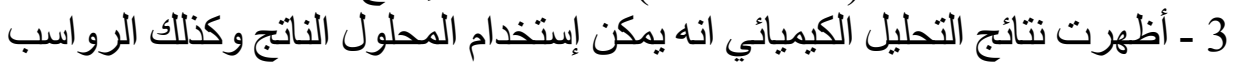

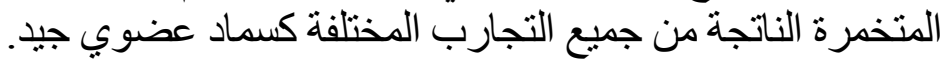

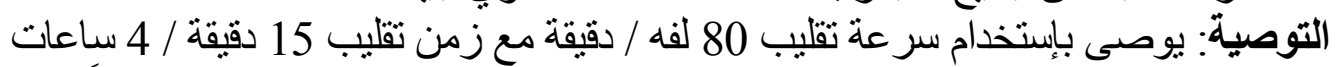
عند درجة حرارة 40 درجة مئوية ونسبة مواد صلبة كلية 10 \% وزمن مكوث لتهن 45 يوماً. 